\title{
Seed dispersal by a diurnal primate community in the Dja Reserve, Cameroon
}

\author{
JOHN R. POULSEN*1, GONNIE J. CLARK* and THOMAS B. SMITH* ${ }^{* 1}$ \\ * Center for Tropical Research and Department of Biology, San Francisco State University, \\ 1600 Holloway Avenue, San Francisco, CA 94132, USA \\ + Center for Population Biology, University of California, Davis, Davis, CA 95616, USA \\ (Accepted 29th March 2001)
}

\begin{abstract}
Multiple species of primate disperse seeds and differentially contribute to the seed rain in tropical forests. The goal of this study was to examine seed dispersal by a primate community of five monkey and two ape species in the Dja Reserve, Cameroon. The density of primates in the reserve was calculated to be 77 individuals $\mathrm{km}^{-2}$. Analysis of 5789 faecal clumps demonstrated that $40 \%$ of monkey and $74 \%$ of ape faecal clumps possessed whole seeds. Six of the seven focal species acted as seed dispersers; faecal clumps passed by the black-and-white colobus (Colobus guereza) did not contain any whole seeds during the study. Seed passage trials on four captive monkey species showed monkeys to have an average seed passage time of 22 hours and defecation rate of five times per day. From the above results, the primate community was estimated to defecate 1129 seeds km $\mathrm{km}^{-2}$ $\mathrm{d}^{-1}$. Seeds passed by the primate community came from 125 species of trees, lianas and shrubs, equivalent to at least $34 \%$ of the known tree flora. Rarefaction curves indicated that additional collection effort would identify more seed species passed by primates. Germination studies demonstrated that primate-passed seeds are viable. The number of seeds and plant species dispersed suggests that the primate community plays an important role in the maintenance of forest structure.
\end{abstract}

KEY WORDS: Cercopithecus, Gorilla gorilla, Lophocebus, Pan troglodytes, primates, seed germination, seed passage, seed shadow

\section{INTRODUCTION}

Primates are recognized as important seed dispersers for tropical plants (Dew \& Wright 1998, Voysey et al. 1999a, Wrangham et al. 1994, Zhang \& Wang 1995). Not only are primates numerically abundant in tropical forests, many species are largely frugivorous (Chapman 1995) and ingest and defecate or drop large numbers of seeds (Corlett \& Lucas 1990, Stevenson 2000, Wrangham et al. 1994). By moving seeds away from the parent plant, primates

${ }^{1}$ Corresponding author. The Wildlife Conservation Society, Project Lac Télé, B.P. 14537, Brazzaville, Congo. Email: wcslactele@unplus.com 
can influence seed deposition patterns of tropical plants that likely contribute to forest structure.

The quality of a particular seed disperser for a plant species depends on three criteria: (1) the number of seeds dispersed; (2) the germination potential of the seed after handling or gut passage; and (3) the suitability of the microsite for germination where the seed is deposited (Chapman 1995, Schupp 1993). Primate species vary considerably in these aspects of seed dispersal and demonstrate a variety of movement patterns and fruit processing techniques that will ultimately influence the deposition of seeds (Kaplin \& Moermond 1998, Lambert 1999).

Strict one-to-one relationships in which a plant relies on a single seed disperser are rare (but see Tutin et al. 1991), and plant species often possess several dispersers. Studies in Gabon, Uganda and Cameroon illustrate the lack of specificity of frugivores for plant species (Chapman 1995, Gautier-Hion et al. 1985, Poulsen et al. 2001), though Poulsen et al. (in press) found frugivorous birds and primates to feed on and disperse different suites of plant species. Because seed dispersal is commonly an interaction between a plant and multiple dispersers, a more complete understanding of seed dispersal processes may be gained by addressing vertebrate assemblages or communities instead of individual species. A community-level approach has two advantages. First, it may reveal specific differences among seed dispersers that affect patterns of seed deposition. As a result, groups of frugivores that disperse a similar suite of plant species in a manner that results in similar patterns of seed deposition may be identified as disperser assemblages. Second, with knowledge of the plant species dispersed by frugivores, a community-level approach enables the estimation of the relative contribution of frugivores to the seed rain and seed shadows of plant species.

This study examined seed dispersal by seven diurnal primates in the Dja Reserve, Cameroon to assess the role of the primate community in an early stage of seed dispersal - transport of seeds away from the plant. Specific objectives were: (1) to determine whether the seven primates in the Dja Reserve are effective seed dispersers, as defined by the first two criteria above; (2) to include information on the relative importance of primate species with regard to number of species and seeds dispersed; (3) to evaluate overlap among primate species in the plant species dispersed; and (4) to compare patterns of seed deposition generated by monkeys versus those produced by apes.

\section{METHODS}

Study area and target species

We conducted this study in the Dja Biosphere Reserve, south-central Cameroon. The reserve encompasses $526 \mathrm{~km}^{2}$, making it the largest protected area in Cameroon. Our study area was a $25-\mathrm{km}^{2}$ site centred on the Bouamir Research Station. The vegetation is semi-deciduous tropical rain forest 
(Letouzey 1968) and has never been logged. Small-scale agriculture took place at one corner of the study site more than 90 y ago (Whitney \& Smith 1998), but evidence of past farming is nearly imperceptible. The main study area contains primary forest, Uapaca forest, Raphia swamp, and inselberg habitat (rock outcroppings frequently covered by shallow soils and grasses) (Whitney et al. 1998). The climate is characterized by two wet and two dry seasons, with major and minor rainfall peaks in September and May, respectively. Average annual rainfall at the study site is $c$. $1600 \mathrm{~mm}$ (Poulsen unpubl. data, Whitney \& Smith 1998).

We investigated seed dispersal by seven species of diurnal primate found in the study area. Target species included four species of Cercopithecidae monkey: the grey-cheeked mangabey Lophocebus albigena albigena, moustached monkey Cercopithecus cephus cephus, white-nosed guenon Cercopithecus nictitans nictitans, and crowned guenon Cercopithecus mona pogonias; one Colobidae, the blackand-white colobus Colobus guereza occidentalis; and two great apes: chimpanzee Pan troglodytes troglodytes and gorilla Gorilla gorilla gorilla. On rare occasions, we observed three other diurnal primate species on the study area, the agile mangabey Cercocebus agilis, talapoin monkey Miopithecus talapoin, and de Brazza's monkey Cercopithecus neglectus. However, these species did not occur at high enough densities on the study area to be included in this study.

\section{Primate survey methods and density estimates}

We calculated primate densities as the first step towards determining the number and density of seeds dispersed by primates in the Dja Reserve. Primates were surveyed using modified line-transects based on the distance sampling methods of Buckland et al. (1993) and described in detail in Whitney \& Smith (1998) and Poulsen et al. (2001). To avoid disturbance associated with constructing a transect grid, researchers walked sections of a $34.5-\mathrm{km}$ network of former hunting trails to census frugivores. The trail system traverses all major habitats in the study area (Whitney \& Smith 1998) and is composed of seven loops, ranging in distance from 6.0 to $7.5 \mathrm{~km}$, that collectively sample the entire study site. The loops were walked in sequence so that all seven loops were surveyed before the first loop was re-sampled. In addition, we alternated the direction that a loop was sampled so that it was never walked in the same direction in two consecutive surveys. Each loop was walked at least three times per month, with the exception of January, resulting in at least 21 surveys per month $($ mean $=137.5 \mathrm{~km}, \mathrm{SD}=16.2$, range $=80-150)$. Between 06h00-11h00, one researcher and one local Baka guide walked trails at a pace of approximately $2.5 \mathrm{~km} \mathrm{~h}^{-1}$. For each group of primates encountered, the researcher recorded the species, group size, distance, compass bearing of the group, time, and habitat type. Distances were estimated to the group centre (Whitesides et al. 1988) by eye to the nearest metre. Researchers occasionally left the trail to confirm group size, but all groups were initially detected from the transect line. 
From the transect data, we estimated densities of primate groups using the program DISTANGE (Laake et al. 1993). Density estimations were performed for the five arboreal primates in the primate community that met the minimum statistical requirement of 60-80 sightings (Buckland et al. 1993). We made too few observations on chimpanzees and gorillas at BRS to estimate densities and biomass; and therefore, use estimates of ape density for the Dja Reserve from Williamson \& Usongo (1996). Approximately 10\% of the observations - those farthest from the transect line - were excluded from the analysis to improve model estimation (Buckland et al. 1993), resulting in a truncated transect width. DISTANCE models the distance from a transect to an animal using several density functions so that the density of animals in a study area can be estimated. Akaike's Information Criterion (AIC) was computed for each candidate model, and the model with the lowest AIC was selected (Buckland et al. 1993). Densities of individuals were calculated as the product of group density and mean group size, where mean group sizes were based on a subset of observations for which we were confident that all group members were counted.

\section{Seed treatment and analysis of faecal clumps}

The treatment of seeds by primates was determined by behavioural observations on non-habituated foraging monkeys during surveys and on one group of habituated grey-cheeked mangabeys (Poulsen et al. 2001). Whenever foraging primates were encountered, the fruit species being consumed and the treatment of the seed (swallowed, dropped, destroyed) was recorded. In addition, faeces were collected opportunistically during surveys of primate abundance or while we followed the group of habituated grey-cheeked mangabeys. Whenever a monkey was observed to defecate, we collected the faecal clump and wrapped it in a plastic bag marked with the species name of the monkey. In some cases monkey faecal clumps were collected without direct observation of the defecation. These clumps were pooled as defecations of unknown origin. We also collected chimpanzee and gorilla faecal clumps along trails. Chimpanzee and gorilla faecal clumps are easily distinguished by their size, shape and odour. Samples were immediately returned to the field station for processing.

We washed all faecal clumps with water over a $1.5-\mathrm{mm}$ screen, and extracted seeds longer than $2 \mathrm{~mm}$. For large-seeded species $(>2 \mathrm{~mm})$, we counted the exact number of seeds in a faecal clump. The abundance of small seeds $(<2$ $\mathrm{mm}$ ) was estimated to the nearest hundred seeds because a single faecal sample could contain, for example, thousands of Ficus seeds. We determined the species of seeds by comparing them to a reference collection of seeds from identified fruits. Seeds that could not be identified were assigned a temporary identification code; and we routinely collected fruits from the forest floor to compare them with unidentified seeds.

Because most of the faecal clumps collected for grey-cheeked mangabeys came from one group of $c .22$ individuals, these data may be biased by pseudoreplication. However, faecal clumps collected from other species of monkey are 
unlikely to be biased in this way because they were collected opportunistically across the study area.

\section{Seed passage trials and seed movement distances}

We conducted seed passage trials of captive monkeys to determine the approximate length of time between ingestion and defecation of seeds by primates. Trials were conducted on the tana mangabey Cercocebus galeritus, redcapped mangabey Cercocebus torquatus, white-nosed guenon, and mona monkey Cercopithecus mona mona. All individuals were wild-caught adults housed at the Limbé Zoo, Limbé, Cameroon. Only one of our target monkey species was housed at the zoo; therefore we used the species above because they are taxonomically close to those of the Dja Reserve and of similar body masses (Kingdon 1997, Smith \& Jungers 1997) (Table 1 and Table 4).

We gave the monkeys foods they had not consumed in the previous $48 \mathrm{~h}$, including Ziziphus sp., Aframomum sp., Pseudospondias macrocarpus, Citrus sp., corn, watermelon, tomato and papaya. These foods were chosen over fruit species commonly consumed by wild primates in the Dja Reserve because the captive primates were accustomed to eating them, and new foods may have upset digestion and altered seed passage times. An observer watched the primates in cages for $48 \mathrm{~h}$ after the commencement of the trial. The observer recorded the time of defecation and analysed faecal clumps for seeds or pieces of food. The mean retention time (MRT) was calculated as the average defecation time of all food items (Maisels 1993).

The distance seeds are moved from the parent plant depends on both the seed passage rates and distance moved by monkeys. To determine the daily distance travelled by monkeys, we took GPS readings of the location of a group of grey-cheeked mangabeys at $06 \mathrm{~h} 00$ and $18 \mathrm{~h} 00$. Movement data are only available for one group of habituated grey-cheeked mangabeys, as unhabituated monkeys were impossible to follow from dawn to dusk. Therefore, this distance represents the average straight-line distance travelled during the day for greycheeked mangabeys.

\section{Germination of passed seeds}

To assess whether primate-passed seeds were viable, we extracted undamaged seeds of known species from faecal samples for germination trials. We placed seeds in moist cloth towelling and watered them every other day or planted them in a germination garden located at the edge of a $100-\mathrm{m}^{2}$ gap. We planted 4-5 seeds in 1-litre nursery bags at a depth of $1 \mathrm{~cm}$ and watered and examined the bags for seedlings every $3 \mathrm{~d}$. Following germination, seedlings were removed or marked with a small stick to avoid double-counting.

To compare germination rates of passed and non-passed seeds, we collected seeds of Uapaca (Euphorbiaceae) species from ripe fruits under the canopies of fruiting trees. We selected Uapaca species because they were the most common seeds in primate faeces and their fruits were important in the diets of primates 
(Poulsen et al. 2001). These seeds were planted and monitored in the same fashion as passed seeds.

\section{Statistical analyses}

We used contingency tables to test for differences in germination rates of passed and non-passed Uapaca seeds. Non-parametric Mann-Whitney U-tests identified differences in seed passage rates between males and females of the same species. Kruskal-Wallis non-parametric ANOVA tested for differences in seed passage rates among monkey species. Because the number of faecal clumps collected for each primate species was unequal, we estimated rarefaction curves for the number of seed species expected to be detected under different sampling efforts (Gotelli \& Graves 1996). We calculated rarefaction curves using the program Ecosim version 5.53. Overlap in the species of seed passed by primates was calculated simply as the number of species two primate species passed in common. Unless otherwise indicated, all analyses were performed using SPSS version 9.0.

\section{RESULTS}

Primate densities and biomass

We estimated the density of primates at BRS to be 77 primates $\mathrm{km}^{-2}$ and the overall biomass of these seven species to be $645 \mathrm{~kg} \mathrm{~km}^{-2}$ (Table 1). The crowned guenon occurred at the highest densities, whereas chimpanzees had the lowest densities. Despite their low densities, gorillas accounted for nearly a third of the primate biomass.

Table 1. Density of monkeys in the Dja Reserve, Cameroon. WNG, white-nosed guenon; CRG, crowned guenon; MM, moustached monkey; GCM, grey-cheeked mangabey; BWC, black-and-white colobus; GOR, gorilla; CHP, chimpanzee; Ind., individuals.

\begin{tabular}{|c|c|c|c|c|c|c|}
\hline Species & $\begin{array}{l}\text { Mass } \\
(\mathrm{kg})^{1}\end{array}$ & $\mathrm{n}$ & $\begin{array}{l}\text { Density } \\
\text { (ind. } \mathrm{km}^{-2} \text { ) }\end{array}$ & $\begin{array}{l}\text { 95\% Lower } \\
\text { CL (ind. } \mathrm{km}^{-2} \text { ) }\end{array}$ & $\begin{array}{l}\text { 95\% Upper } \\
\text { CL (ind. } \mathrm{km}^{-2} \text { ) }\end{array}$ & $\begin{array}{l}\text { Biomass } \\
\left(\mathrm{kg} \mathrm{km}^{-2}\right)\end{array}$ \\
\hline$\overline{W N G}$ & 5.5 & 981 & $14.7^{3}$ & 13.4 & 16.2 & 80.9 \\
\hline CRG & 3.6 & 666 & $24.6^{2}$ & 21.6 & 28.0 & 88.6 \\
\hline MM & 3.6 & 249 & $10.3^{2}$ & 8.7 & 12.3 & 37.1 \\
\hline GCM & 6.8 & 705 & $19.7^{2}$ & 17.6 & 21.9 & 134.0 \\
\hline BWC & 11.4 & 176 & $4.9^{2}$ & 4.0 & 6.2 & 55.9 \\
\hline $\mathrm{GOR}^{4}$ & 121.5 & & 1.7 & & : $1.0-2.9)$ & 206.6 \\
\hline $\mathrm{CHP}^{4}$ & 52.8 & & 0.8 & & : $0.6-1.0)$ & 42.2 \\
\hline Total & & 2777 & 76.7 & & & 645.3 \\
\hline
\end{tabular}

${ }^{1}$ Mean body masses are based on the midpoint of the mean adult male mass and mean adult female mass from Smith \& Jungers (1997).

${ }^{2}$ Half-normal model. WNG (AIC: half-normal $=8388.0$, uniform $=8388.6$ ).

${ }^{3}$ Uniform model. CRG (AIC: half-normal $=5721.3$, uniform $\left.=5722.4\right)$, MM (AIC: half-normal = 1620.5, uniform = 1620.9), GCM (AIC: half-normal = 5951.7, uniform = 5952.2), BWC (AIC: half-normal = 1495.9, uniform = 1497.2).

${ }^{4}$ Gorilla and chimpanzee densities are from Williamson \& Usongo (1996). 


\section{Passage of seeds}

Six of the seven diurnal primates in the Dja Reserve commonly passed seeds in their faeces. Out of 48 faecal clumps, the black-and-white colobus passed only a single immature seed piece, and therefore, probably is not an important seed disperser in the reserve. Three-quarters of faecal clumps passed by chimpanzees and gorillas contained intact whole seeds; whereas less than half of monkey faecal clumps contained seeds (Table 2). While primates dispersed a relatively large percentage of whole seeds, they also damaged some seeds during feeding or digestion. All six primates passed a small percentage of clumps (2 to $17 \%$ ) with seed pieces (Table 2).

Table 2. Numbers of faecal clumps and seeds defecated by all primate species. Numbers in parentheses are percentages of total faecal clumps. WNG, white-nosed guenon; CRG, crowned guenon; MM, moustached monkey; GCM, grey-cheeked mangabey; BWC, black and white colobus; GOR, gorilla; CHP, chimpanzee; UNK, unknown.

\begin{tabular}{lccccr}
\hline Species & $\begin{array}{l}\text { Faecal } \\
\text { clumps }\end{array}$ & $\begin{array}{l}\text { Clumps with } \\
\text { whole seeds }\end{array}$ & $\begin{array}{l}\text { Clumps with } \\
\text { seed pieces }\end{array}$ & $\begin{array}{l}\text { Seeds per clump } \\
\text { mean } \pm \text { SD }\end{array}$ & $\begin{array}{l}\text { Number of } \\
\text { species of seed }\end{array}$ \\
\hline WNG & 402 & $172(42.8)$ & $3(0.7)$ & $1.0 \pm 1.9$ & 32 \\
GRG & 75 & $41(54.7)$ & $13(17.3)$ & $2.1 \pm 3.4$ & 5 \\
MM & 83 & $31(37.3)$ & $5(6.0)$ & $1.5 \pm 2.9$ & 5 \\
GGM & 3070 & $1034(33.7)$ & $235(7.7)$ & $1.6 \pm 26.4$ & 61 \\
BWC & 48 & $0(0)$ & $1(2.1)$ & $0 \pm 0$ & 0 \\
GOR & 87 & $64(73.6)$ & $2(2.3)$ & $40.8 \pm 262.6$ & 24 \\
CHP & 178 & $132(74.2)$ & $13(7.3)$ & $18.0 \pm 142.4$ & 44 \\
UNK & 771 & $413(53.6)$ & $16(2.1)$ & $1.9 \pm 31.2$ & 49 \\
Total & 5789 & & & & $125^{1}$ \\
\hline
\end{tabular}

${ }^{1}$ Total number of species passed by the primate community.

To determine the rate of seed deposition by primates, the number of seeds passed per faecal clump was calculated. Chimpanzees and gorillas passed 18 and 41 seeds per faecal sample, respectively. The smaller arboreal monkeys defecated between one and two seeds per faecal sample (Table 2). Chimpanzee and gorilla faecal clumps weighed $(\mathrm{g} \pm \mathrm{SD}) 65.7 \pm 60.5$ and $133.2 \pm 94.6$, respectively. The average masses of monkey faecal clumps ranged from 3.0 to $8.0 \mathrm{~g}$. Thus, the number of seeds per faecal clump is related to the mass of the faecal clump.

Because the seed density at the time of deposition may influence later recruitment, data were re-examined, excluding all faecal clumps with no seeds, to determine average seed density in a single faecal clump. Of all faecal clumps that contained whole seeds, chimpanzees averaged 24, gorillas 56, moustached monkeys 4, white-nosed guenons 2, crowned guenons 4, and grey-cheeked mangabeys 5 large seeds per faecal clump. With respect to faecal clumps that contained whole seeds, chimpanzees and gorillas passed 1.7 species of seed per defecation on average. Monkeys passed between 1.0 and 1.1 species of seed per faecal sample (Table 2).

The entire primate community dispersed the seeds of 125 plant species, 59 
of which could be identified to species. The grey-cheeked mangabey passed the greatest number of species (Table 2), but this may be a function of larger sample size. Rarefaction curves show that chimpanzees disperse more species of seed than monkeys based on the expected number of seed species to be found in samples of equal sizes (Fig. 1). The curves also demonstrate that, although more species were recorded for the grey-cheeked mangabey than for the other primates, this is due to the much smaller sample sizes of the chimpanzee, gorilla, and white-nosed guenon, which probably disperse more seed species for a given sample of faecal clumps (Table 3). The curves show increasing slopes for each primate species, suggesting that additional collection effort would add new seed species to the lists of species defecated in faecal clumps (Fig. 1).

Many plant species were dispersed by more than one primate species. Monkeys appear to overlap more with each other in the species they disperse than they do with apes (Fig. 2). Likewise, apes disperse more species of seed in common with each other than with monkeys. The percentage of species shared among primates ranged from $7 \%$ to $50 \%$ for primate species that passed at least 20 species of seed.

Primates may be particularly important dispersers of the seeds of Uapaca species. Uapaca spp. was found in $40 \%$ of all chimpanzee and gorilla faecal

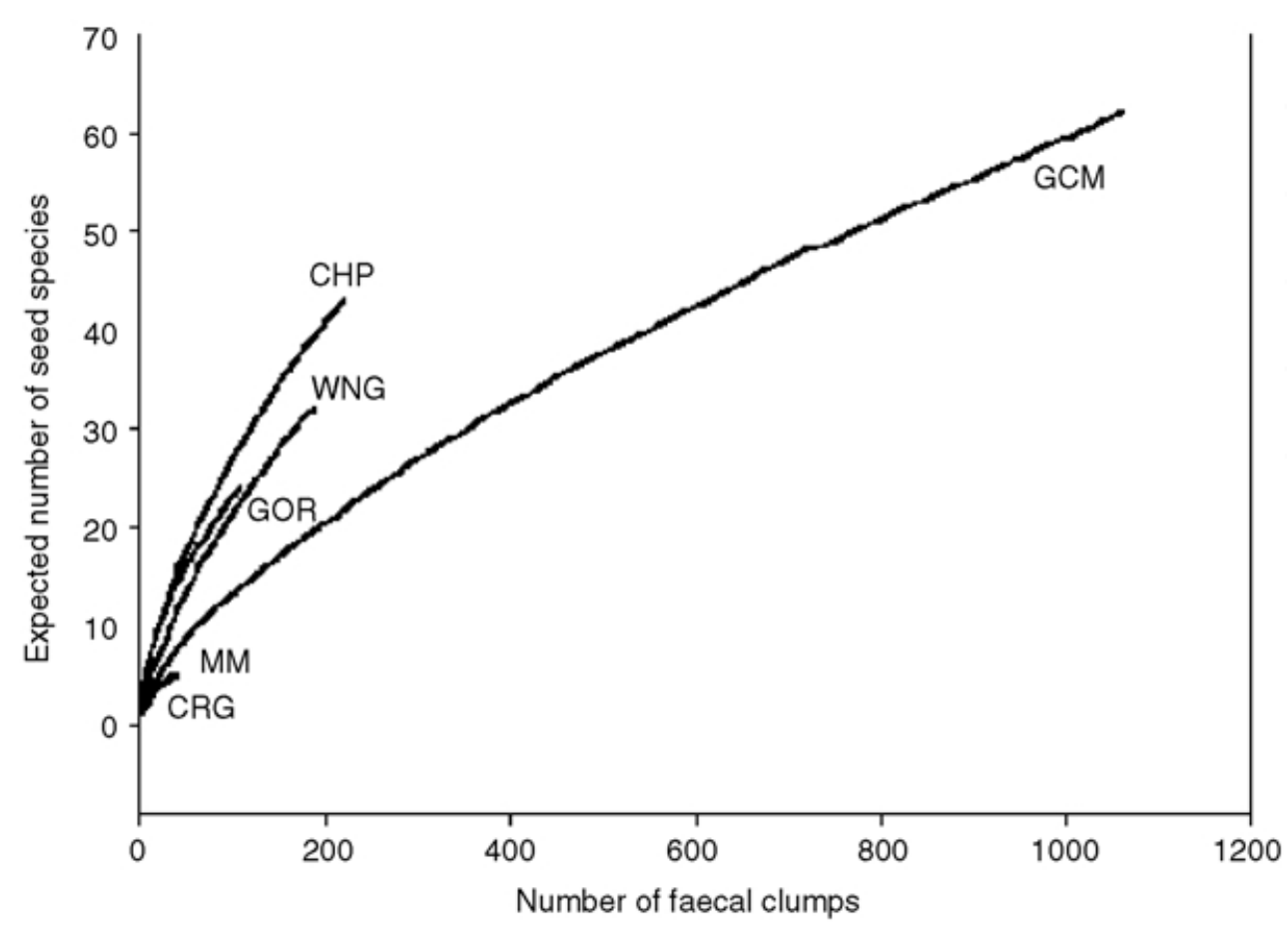

Figure 1. Rarefaction curves of the expected number of seed species detected with increasing numbers of faecal clumps. GCM, grey-cheeked mangabey; WNG, white-nosed guenon; CRG, crowned guenon; MM, moustached monkey; CHP, chimpanzee; GOR, gorilla. 
Table 3. Results of rarefaction of seeds passed in primate faecal clumps. The faecal samples of all primate species were rarefied to the abundance level of the moustached monkey, the primate species with the fewest faecal samples. Therefore, the average diversity is the mean number of seed species expected in 33 faecal clumps. Primate species are listed in order of decreasing average diversity of seed species in faecal clumps. CHP, chimpanzee; GOR, gorilla; WNG, white-nosed guenon; GCM, grey-cheeked mangabey; MM, moustached monkey; GRG, crowned guenon.

\begin{tabular}{lllll}
\hline Species & $\begin{array}{l}\text { Average } \\
\text { diversity }\end{array}$ & $\begin{array}{l}\text { Diversity } \\
\text { variance }\end{array}$ & 95\% Upper CL & 95\% Lower CL \\
\hline CHP & 13.6 & 4.7 & 9.3 & 17.8 \\
GOR & 12.7 & 3.6 & 8.7 & 16.4 \\
WNG & 9.7 & 3.6 & 6.0 & 13.4 \\
GCM & 6.6 & 3.1 & 3.2 & 10.1 \\
MM & 5.0 & 0.0 & 5.0 & 5.0 \\
GRG & 4.7 & 0.3 & 3.6 & 5.8 \\
\hline
\end{tabular}

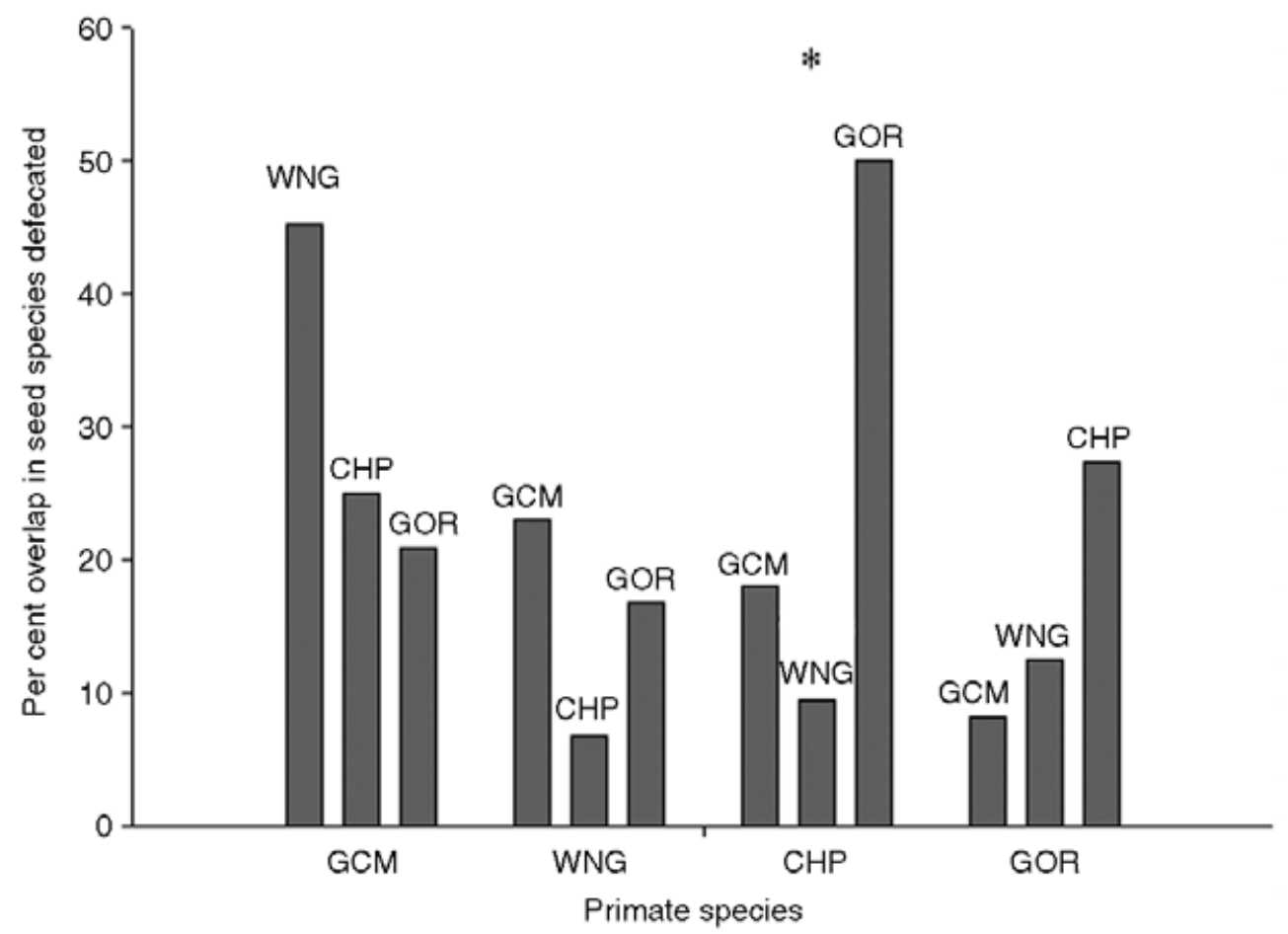

Figure 2. Per cent of seed species shared among primate species. The bars represent the per cent of all seed species passed by species A (above bars) shared by species B (x-axis). The per cent of gorilla-passed seed species shared by chimpanzees was significantly greater than the per cent of grey-cheeked mangabeyand white-nosed guenon-passed species shared by chimpanzees $\left(\chi^{2}=8.14, \mathrm{df}=2, \mathrm{P}<0.025\right)$. There were no significant differences in per cent overlap among primates with the grey-cheeked mangabey, white-nosed guenon, or gorilla. GCM, grey-cheeked mangabey; WNG, white-nosed guenon; GHP, chimpanzee; GOR, gorilla. Only primate species that passed at least 20 species of seed are included. Asterisk denotes statistical significance at $\mathrm{P}<0.05$. 
clumps containing whole seeds; whereas monkeys passed Uapaca spp. in $79 \%$ of the clumps which contained whole seeds. The moustached monkey passed the highest numbers of Uapaca seeds; 88\% of its faecal clumps contained Uapaca spp. The seeds of most other plant species were found only occasionally in primate faeces, occurring in 1 to $11 \%$ of all faeces with seeds.

\section{Seed passage trials and seed movement distances}

The four species of monkey housed at the Limbé Zoo demonstrated an average seed passage time of $22.0 \mathrm{~h}$ (Table 4 ). The mona monkey and tana mangabey had the lowest average retention times, while the white-nosed guenon had

Table 4. Results of gut passage trials. Mean retention time is the average number of hours it took a primate to pass a food item. Trials were conducted on two individuals of each species, one male and one female, with the exception of the white-nosed guenon. The sample size (n) indicates the number of defecations by an individual. Body masses are the average of male and female body masses from Smith \& Jungers (1997).

\begin{tabular}{llrl}
\hline $\begin{array}{l}\text { Primate } \\
\text { species }\end{array}$ & $\begin{array}{l}\text { Body mass } \\
(\mathrm{kg})\end{array}$ & $\mathrm{n}$ & $\begin{array}{l}\text { Mean retention time } \\
(\mathrm{h})( \pm \mathrm{SD})\end{array}$ \\
\hline Tana mangabey & & 11 & $22.8 \pm 1.3$ \\
$\quad$ Male & 9.6 & 9 & $25.4 \pm 4.6$ \\
$\quad \begin{array}{l}\text { Female } \\
\text { Red-capped mangabey }\end{array}$ & 5.3 & 9 & $22.6 \pm 2.0$ \\
$\quad$ Male & 9.5 & 13 & $21.2 \pm 2.0$ \\
$\quad$ Female & 5.5 & 13 & $23.8 \pm 4.8$ \\
White-nosed guenon & & 13 & $22.8 \pm 2.4$ \\
$\quad \begin{array}{l}\text { Male } \\
\text { Male }\end{array}$ & 6.7 & & $21.4 \pm 6.9$ \\
Mona monkey & 6.7 & 10 & $21.7 \pm 7.4$ \\
$\quad \begin{array}{l}\text { Male } \\
\text { Female }\end{array}$ & 5.1 & 9 & \\
\hline
\end{tabular}

the longest average passage time. No significant differences were found between males and females of the same species allowing all data to be pooled. There was no significant difference in mean passage times among the monkey species tested (Kruskal-Wallis: $\chi^{2}=6.86, \mathrm{df}=7, \mathrm{P}=0.443$ ). The average defecation rate for the four monkey species was 5.0 defecations $\mathrm{d}^{-1}(\mathrm{n}=8$ monkeys, range $=3-7$ defecations $\mathrm{d}^{-1}$ ).

Based on GPS readings, habituated grey-cheeked mangabeys travelled an average straight-line distance of $1157 \mathrm{~m}(\mathrm{n}=16 \mathrm{~d})$. Therefore, an average seed passage time of $22 \mathrm{~h}$ allows grey-cheeked mangabeys to disperse ingested seeds over $1 \mathrm{~km}$ from the parent plant. The daily distance travelled by grey-cheeked mangabeys ranged from 570 to $2240 \mathrm{~m}$, indicating that dispersal distances may vary considerably from day to day.

Number of seeds dispersed by the primate community

The number of seeds dispersed by monkeys is a function of monkey densities $\times$ defecation rate $\times$ the number of seeds deposited per faecal clump. Calculated in this fashion, primates deposited 1129 seeds km $\mathrm{km}^{-2} \mathrm{~d}^{-1}$ (696-1749 seeds km $\mathrm{km}^{-2}$ $\left.\mathrm{d}^{-1}\right)$. Of these seeds, arboreal monkeys dispersed 568 seeds $\mathrm{km}^{-2} \mathrm{~d}^{-1}(350-835$ 
Table 5. Number of seeds deposited $\mathrm{km}^{-2} \mathrm{~d}^{-1}$ by primates in the Dja Reserve, Cameroon. The average density of seeds dispersed was calculated: density of primates $\times$ defecation rate $\times$ seeds per defecation. The lower and upper ranges of seeds dispersed were calculated: lower/upper range of primate densities $\times$ lower/ upper range of defecation rates $\times$ average seeds per defecation. (The range of seeds per defecation was not included in calculations because the lower range is zero seeds per defecation in all cases.) WNG, white-nosed guenon; CRG, crowned guenon; MM, moustached monkey; GCM, grey-cheeked mangabey; GOR, gorilla; CHP, chimpanzee.

\begin{tabular}{|c|c|c|c|c|}
\hline Species & Individual $\mathrm{km}^{-2}$ & No. of defecations $\mathrm{d}^{-1}$ & No. of seeds defecation ${ }^{-1}$ & Seeds $\mathrm{km}^{-2} \mathrm{~d}^{-1}$ \\
\hline WNG & $14.7(13.4-16.2)$ & $5 \pm 1.5^{1}$ & $1.0 \pm 1.9$ & $73.5(46.9-105.3)$ \\
\hline CRG & $24.6(21.6-28.0)$ & $5 \pm 1.5^{1}$ & $2.1 \pm 3.4$ & $258.3(158.8-382.2)$ \\
\hline MM & $10.3(8.7-12.3)$ & $5 \pm 1.5^{1}$ & $1.5 \pm 2.9$ & $77.3(45.7-120.0)$ \\
\hline GCM & $19.7(17.6-21.9)$ & $5 \pm 1.5^{1}$ & $1.6 \pm 26.4$ & $158.6(98.6-227.8)$ \\
\hline GOR & $1.7(1.0-2.9)$ & $6.7^{2}$ & $40.8 \pm 262.6$ & $464.7(273.4-792.7)$ \\
\hline CHP & $0.8(0.6-1.0)$ & $6.7^{2}$ & $18.0 \pm 142.4$ & $96.5(72.4-120.6)$ \\
\hline Total & & & & $1128.9(695.8-1748.6)$ \\
\hline
\end{tabular}

1 The defecation rate was estimated as the average rate of the four monkey species in our seed passage trials $(n=8)$.

${ }^{2}$ Defecation rate of chimpanzees in the Gombe National Park from Wrangham et al. (1994).

$\left.\mathrm{km}^{-2} \mathrm{~d}^{-1}\right)$ and apes dispersed 561 seeds $\mathrm{km}^{-2} \mathrm{~d}^{-1}\left(346-913 \mathrm{~km}^{-2} \mathrm{~d}^{-1}\right)$ (Table 5). Thus, despite their lower densities in the Dja Reserve, apes contribute to nearly one-half of all primate-dispersed seeds. Individually, monkeys deposit fewer seeds, but their high densities compared to apes also make monkeys important seed dispersers in terms of the number of seeds dispersed.

\section{Germination of passed seeds}

All six of the primate species passed viable seeds - at least one species of seed passed by each primate species germinated successfully. Of 33 species of primate-passed seed that we attempted to germinate, 24 species (73\%) successfully germinated (Table 6). Another three species were found germinating in collection bags before they could be planted. Of the nine species that did not germinate, three had sample sizes of less than four seeds.

Germination trials on Uapaca species suggest that passage through the gut of primates may enhance its germination success. Of 267 Uapaca seeds collected from ripe fruits under the canopies of several trees, only 26\% (69) germinated. Germination success of primate-passed Uapaca seeds averaged 50\% (87 of 175) and was significantly higher than germination of non-passed seeds $\left(\chi^{2}=12.3\right.$, $\mathrm{df}=1, \mathrm{P}<0.001)$. Seeds passed by gorillas had the highest germination rate (62\%) and those passed by the crowned guenon had the lowest (38\%).

\section{DISCUSSION}

Our community-level examination of seed dispersal suggests that the primate community plays a large role in the dissemination of seeds in the Dja Reserve. Six of seven primate species (the exception being the largely folivorous blackand-white colobus) passed whole seeds viable for germination. These primate species satisfy the first two requirements necessary to be considered effective 
Table 6. Number of primate-passed seeds that germinated in nursery bags or in damp cloth treatment. Total number of seeds planted are represented in parentheses. Asterisks indicate that the seeds were neither planted nor treated, but found germinating within plastic bags before planting. GCM, grey-cheeked mangabey; WNG, white-nosed guenon; CRG, crowned guenon; MM, moustached monkey; CHP, chimpanzee; GOR, gorilla; ??, not known how many seeds were planted.

\begin{tabular}{|c|c|c|c|c|c|c|}
\hline Seed species & GCM & WNG & CRG & MM & CHP & GOR \\
\hline Antrocaryon klaineanum & - & - & - & - & $3(24)$ & - \\
\hline Cephaelis sp. & - & $0(6)$ & - & - & - & - \\
\hline \multirow{2}{*}{ Cissus dinklagei } & $1(4)$ & $4(4)$ & - & - & - & - \\
\hline & $1(1)^{*}$ & - & - & - & - & - \\
\hline Duboscia macrocarpa & - & - & - & - & 5 (??) & $106(112)$ \\
\hline Enantia chlorantha & - & - & - & - & $118(129)$ & - \\
\hline Erythrophleum suaveolens & - & - & - & - & $0(4)$ & - \\
\hline Euphorbiaceae sp. & - & - & - & - & - & - \\
\hline Ficus spp. & - & $5(24)$ & - & - & - & $50(100)$ \\
\hline \multirow{2}{*}{ Gambeya boukokoensis } & - & - & - & - & - & - \\
\hline & - & - & - & - & - & - \\
\hline Garcinia sp. & - & - & - & - & - & - \\
\hline Grewia hookerana & $0(12)$ & $4(8)$ & - & - & - & - \\
\hline Heisteria zimmereri & - & - & - & - & - & - \\
\hline Hexalobus crispiflorus & - & $0(1)$ & - & - & - & - \\
\hline Landolphia sp. & - & - & - & - & - & - \\
\hline Lannea welwitchii & - & - & - & - & - & - \\
\hline Maesopsis eminii & $1(1)$ & - & - & - & - & - \\
\hline Margaritia discoidea & $0(28)$ & - & - & - & - & - \\
\hline Myranthus arboreus & $0(3)$ & - & - & - & $2(2) *$ & - \\
\hline \multirow[t]{2}{*}{ Plagiostylus africanus } & - & $9(98)$ & - & - & - & - \\
\hline & - & $11(56)$ & - & - & - & - \\
\hline Santiria trimera & - & - & - & - & - & - \\
\hline Sarcophrynium prionogonium & - & - & - & - & $1(2)$ & - \\
\hline Synsepalum stipulatum & - & - & - & - & - & - \\
\hline Trichostachys sp. & $0(1)$ & $2(2)^{*}$ & - & - & $0(2)$ & - \\
\hline Turreanthus africanus & $5(5)$ & - & - & - & - & - \\
\hline \multirow[t]{2}{*}{ Uapaca spp. ${ }^{1}$} & $21(67)$ & - & $2(2)$ & - & $19(48)$ & $19(32)$ \\
\hline & $224(404) *$ & $21(37)^{*}$ & $34(94) *$ & $17(28)^{*}$ & $51(96)^{*}$ & $2(2) *$ \\
\hline Vitex rivularis & - & - & - & - & - & - \\
\hline Vitex sp. & - & - & - & - & $4(18)$ & - \\
\hline Xylopia rubescens & $8(23)$ & - & - & - & - & - \\
\hline Xylopia staudtii & $4(42)$ & - & - & - & - & - \\
\hline
\end{tabular}

${ }^{1}$ Seeds of Uapaca species are nearly indistinguishable. Four species are found on the study area: Uapaca acuminata, U. guineensis, U. paludosa and U. vanhouttei.

seed dispersers: (1) they dispersed a large number of seeds and species, and (2) they passed viable seeds. Testing the fate of seeds deposited by primates was beyond the scope of this study. This study reports the number of seeds and species deposited by the primate community and suggests that the dispersal methods of apes and monkeys may result in different patterns of seedling and adult recruitment. By dispersing the seeds of many tropical plant species, the primate community may influence forest structure in the Dja Reserve. However, to determine the actual contribution of primates to forest structure, seed fate and plant recruitment must be followed to establishment. 
Number of seeds and seed species dispersed

Primates in the Dja Reserve may be effective seed dispersers because they disseminate large numbers of seeds. This begs the question: at the forest community level, how many seeds constitute a large number? We found the primate community to disperse 1146 seeds $\mathrm{d}^{-1}$. However, other studies have found that arboreal frugivores disperse a small percentage (12\%) of the overall seed crops in tropical forests (Clark et al. in press). Therefore, we are left to compare the relative contributions of vertebrate species or disperser assemblages to the seed rain. It is tempting to suggest that the density of seed dispersers may determine their relative importance. The fact that the two apes had the lowest densities of all the primates, but accounted for one-half of the seeds dispersed by the primate community, demonstrates that density of frugivores does not accurately predict their contribution to the seed rain. Furthermore, Clark et al. (in press) determined that large frugivorous birds (hornbills and touracos) in the Dja Reserve contributed more seeds to the seed rain than four species of monkey, despite having lower densities than the monkeys (Whitney \& Smith 1998). Therefore, it is difficult to compare disperser assemblages without a complete knowledge of the number of seeds dispersed by all frugivores in the community.

Perhaps a better indicator of a frugivore's importance as a seed disperser to the forest community is the number of species it disperses. Primates dispersed the seeds of at least 125 plant species through faecal clumps. To date, 230 tree species have been identified on the study site (M. Fogiel, unpubl. data). Thus, collectively ape and monkey species provide seed dispersal for at least 77 of 230 tree species, equivalent to $34 \%$ of the known tree flora of the study area. Primates also dispersed the seeds of at least 25 species of liana and three species of shrub. Similarly, a seed-trap study conducted concurrently at BRS determined that four monkey species alone passed 128 plant species (97 of which were identified to species), accounting for $32 \%$ of all species recorded in the seed rain between May 1998 and May 1999 (Clark, unpubl. data). Our results indicate that the primate community disperses a larger number of seed species than elephants (Loxodonta africana) at the Lopé Reserve, Gabon (White et al. 1991), and three species of Ceratogymna hornbills at the Dja Reserve, Cameroon (Whitney et al. 1998).

In addition to dispersing a third of the tree flora, primates meet the second requirement of effective seed dispersers: they pass seeds viable for germination. Seventy-three per cent of the species passed by these six primates germinated successfully. Sample sizes were low and further germination trials may reveal even greater percentages of germination success. In fact, passage through a primate's gut may actually improve the rate of germination. All primate species passed the seeds of Uapaca species, and germination success was significantly higher in passed than in non-passed seeds. However, our results should be interpreted cautiously because we only compared germination 
rates of passed seeds to non-passed seeds for one plant species. Furthermore, if primates preferentially select healthy fruits with viable seeds in the forest canopy, fruits gathered from the forest floor for germination tests may have been less fit than fruits eaten by primates and less likely to germinate. These results contribute to the growing body of evidence demonstrating that seeds dispersed by primates are capable of germination (Estrada \& Coates-Estrada 1984, Garber 1986, Lieberman \& Lieberman 1986, Wrangham et al. 1994).

\section{Comparison of dispersal methods between monkeys and apes}

In the Dja Reserve the percentage of monkey faecal clumps that contain seeds is low (44\%) compared to chimpanzees, gorillas and many New World monkeys (Lambert 1999, Rowell \& Mitchell 1991, Stevenson 2000). This has led to a characterization of African monkeys as seed-spitters, and therefore, inferior seed dispersers compared to frugivorous birds, apes and elephants because monkeys sometimes damage seeds and move seeds shorter distances from the parent plant (Lucas \& Corlett 1998, Rowell \& Mitchell 1991). African monkeys do drop seeds and fruits directly under the parent plant, but they also move some seeds away from the parent plant by drop dispersal. When seeds are moved outside the canopy of the plant, habituated grey-cheeked mangabeys transported seeds from 5 to $130 \mathrm{~m}$ from the parent, averaging a distance of 42 $\mathrm{m}(\mathrm{n}=52)$. Moreover, monkeys dispersed 15 tree species solely by dropdispersal, and many species were dispersed by both defecation and dropdispersal. Thus, neither defecation nor seed-spitting is necessarily superior to the other, as either dispersal method may be neutral, beneficial or detrimental to seeds depending upon the tree species and habitat (Lambert 1999).

Chimpanzees and gorillas are likely effective seed dispersers because individually they defecate large numbers of seeds. In contrast to arboreal monkeys, a high percentage of chimpanzee and gorilla defecations contain seeds. But, whereas monkeys disperse seeds singly or in small clumps, chimpanzees and gorillas deposit large numbers of seeds in a single faecal clump. Few seeds in a large clump can survive to adulthood; therefore most ape-dispersed seeds probably face density-dependent mortality. However, Voysey et al. (1999b) showed gorillas to be effective seed dispersers because they treat seeds benignly and direct seeds to sites favourable for establishment. Furthermore, the large size of chimpanzees and gorillas may amplify their importance as seed dispersers. Large-bodied frugivores may be the only important dispersers for plant species such as Cola lizae, seeds of which measure $35 \mathrm{~mm}$ in length (Tutin et al. 1991).

The primate community may comprise two dispersal assemblages relatively different from each other in the plant species they disperse. Although our data on the number of species defecated by primates were limited, results suggest that monkeys may be more alike in the seeds they disperse than are monkeys and apes. Likewise, chimpanzees and gorillas overlap more with each other than with monkeys in the seeds they disperse. Differences in the sets of plant 
species dispersed between monkeys and apes suggest that populations of both monkeys and apes are necessary to ensure natural seed dispersal processes. Gorillas and chimpanzees also overlapped more in diet with each other than with other monkey species in the Lopé Reserve, Gabon (Tutin et al. 1997), but more data are necessary to quantify dietary overlap between monkeys and apes in the Dja Reserve.

\section{Dispersal mechanisms and seed shadows}

Seed dispersal by animals is generally restricted with seed densities high beneath parents and rapidly dropping off with distance (Connell 1971, Janzen 1970). Such distance-restricted dispersal can contribute to recruitment limitation by limiting the chance of a seed hitting a suitable recruitment spot (Schupp et al. in press). The distance primates transport seeds away from parent canopies, a result of their slow seed passage times and daily movement, may increase recruitment. Like differences in seed handling and fruit choice, differences in movement between apes and monkeys may shape the seed shadows of plants they disperse. Arboreal monkeys have day ranges similar to our estimate of the day range of grey-cheeked mangabeys, approximately $1 \mathrm{~km}$ (Cords 1987, Lambert 1999, Melnick \& Pearl 1987). Chimpanzees and gorillas, on the other hand, have dispersal ranges of several $\mathrm{km}\left(1.9-4.3 \mathrm{~km} \mathrm{~d}^{-1}\right)$ (Goodall 1986, Tutin et al. 1991). Thus, plants like Uapaca species, fruits of which are eaten by both monkeys and apes, have a number of consumers that disperse seeds at different distances from the parent plant.

Different mechanisms of dispersal by primates may result in even greater variability in seed shadows for a particular plant. Some large-seeded species like Strombosia grandifolia may be dispersed through defecation by apes and drop-dispersed by grey-cheeked mangabeys and guenons. In this case, the plant benefits from long-distance dispersal on the order of one to several $\mathrm{km}$ from apes and short-distance dispersal from 5 to $140 \mathrm{~m}$ from the smaller, arboreal monkeys. These differential treatments of fruits and seeds by primates may increase the probability that a seed is deposited in a favourable microsite, the location of which is unpredictable (Wheelwright \& Orians 1982).

\section{CONCLUSION}

The reduction of primate abundances may alter seed dispersal, seed predation and seedling recruitment for tropical plants (Wright et al. 1999). In parts of Central Africa, arboreal primate populations have been reduced to a fraction of their historical size due to hunting (Chapman et al. 1999, Muchaal \& Ngandjui 1999, Oates 1999, Struhsaker 1999). Based on the number of seeds and seed species dispersed by primates in the Dja Reserve, the primate community may be imperative to the maintenance of natural forest dynamics and organization. Seed dispersal by primates is now well documented, but more communitylevel studies are necessary to determine the role of primates in seed dispersal 
relative to other frugivores or dispersal assemblages. Moreover, determining whether differential seed handling and movement patterns have consequences for patterns of seedling and adult recruitment are aspects of primate seed dispersal that merit further study.

\section{ACKNOWLEDGEMENTS}

We are grateful to the Republic of Cameroon, in particular the Ministry of Environment and Forests (MINEF) for permission to work in the Dja Reserve. Financial and logistical support was generously provided by ECOFAC Cameroun, the NYZS/Wildlife Conservation Society, the EPA STAR fellowship, the SFSU GAANN programme, the NSF GRT/GAANN, and the Center for Tropical Research. In addition, portions of this research were supported by NSFDEB9726425, NSF-IRCEB0077072, and NIH/MIRT grants to T. Smith. For dedicated and skilful assistance in the field, we thank K. Lucas, C. Nishida, S. Wahaj, S. Hansen, S. Joe, P. Krushelnycky, and the residents of Bifolone and Somalomo, particularly A. Siec, D. Amaziah and J. Mann. R. Sama and G. Mpaul provided invaluable assistance in analysing faecal samples. A. Harcourt, V. Parker, E. Connor, H. Slabbekoorn, C. Graham, K. Holder and two anonymous reviewers provided helpful comments on early drafts of this paper.

\section{LITERATURE GITED}

BUGKLAND, S. T., ANDERSON, D. R., BURNHAM, K. P. \& LAAKE, J. L. 1993. Distance sampling: estimating abundance of biological populations. Chapman \& Hall, London. 446 pp.

CHAPMAN, C. A. 1995. Primate seed dispersal: coevolution and conservation implications. Evolutionary Anthropology 4:74-82.

CHAPMAN, G. A., GAUTIER-HiOn, A., OATES, J. F. \& ONDERDONK, D. A. 1999. African primate communities: determinants of structure and threats to survival. Pp. 1-37 in Fleagle, J. G., Janson, C. \& Reed, K. E. (eds). Primate communities. Cambridge University Press, Cambridge.

CLARK, G. J., POULSEN, J. R. \& PARKER, V. T. In press. Impact of frugivores on seed rain patterns in a central African tropical forest. Biotropica, in press.

CONNELL, J. H. 1971. On the role of natural enemies in preventing competitive exclusion in some marine mammals and in rain forest trees. Pp. 298-312 in Boer, P. J. D. \& Gradwell, G. (eds). Dynamics of populations. PUDOC, Wageningen.

CORDS, M. 1987. Forest guenons and patas monkeys: male-male competition in one-male groups. Pp. 98-111 in Smuts, B. B., Cheney, D. L., Seyfarth, R. M., Wrangham, W. R. \& Struhsaker, T. T. (eds). Primate societies. University of Chicago Press, Chicago.

CORLETT, R. T. \& LUCAS, P. W. 1990. Alternative seed-handling strategies in primates: seed spitting by long-tailed macaques (Macaca fascicularis). Oecologia 82:166-171.

DEW, L. J. \& WRIGHT, P. 1998. Frugivory and seed dispersal by four species of primates in Madagascar's eastern rain forest. Biotropica 30:425-437.

ESTRADA, A. \& COATES-ESTRADA, R. 1984. Fruit eating and seed dispersal by howling monkeys (Alouetta palliata) in the tropical rain forest of Los Tuxtlas, Mexico. American Journal of Primatology 6:77-91.

GARBER, P. 1986. The ecology of seed dispersal in two species of callitrichid primates (Sanguinus mystax and Sanguinus fuscicollis). American Journal of Primatology 10:155-170.

GAUTIER-HION, A., DUPLANTIER, J.-M., QURIS, R., FEER, F., SOURD, C. DEGOUX, J.-P., DUBOST, G., EMMONS, L., ERARD, C., HECKETSWEILER, P., MOUNGAZI, A, ROUSSILHON, C. \& THIOLLAY, J.-M. 1985. Fruit characters as a basis of fruit choice and seed dispersal in a tropical forest vertebrate community. Oecologia 65:324-337.

GOODALL, J. 1986. The chimpanzees of Gombe: patterns of behavior. Harvard University Press, Cambridge. $673 \mathrm{pp}$. 
GOTELLI, N. J. \& GRAVES, G. R. 1996. Null models in ecology. Smithsonian Institution Press, Washington, DG. $368 \mathrm{pp}$.

HUTCHINSON, J., DALZIEL, J. M. \& HEPPER, F. N. 1963. Flora of West Tropical Africa. Second edition. Crown Agents for Overseas Governments and Administrations, London.

JANZEN, D. H. 1970. Herbivores and the number of tree species in tropical forests. American Naturalist 104:501-528.

KAPLIN, B. A. \& MOERMOND, T. C. 1998. Variation in seed handling by two species of forest monkeys in Rwanda. American Journal of Primatology 45:83-101.

KINGDON, J. 1997. The Kingdon field guide to African mammals. Academic Press, San Diego. 488 pp.

LAAKE, J. L., BUCKLAND, S. T., ANDERSON, D. R. \& BURNHAM, K. P. 1993. DISTANCE user's guide. Colorado Cooperative Fish and Wildlife Research Unit, Colorado State University, Fort Collins. $446 \mathrm{pp}$.

LAMBERT, J. E. 1999. Seed handling in chimpanzees (Pan troglodytes) and redtail monkeys (Cercopithecus ascanius): implications for understanding hominoid and cercopithecine fruit-processing strategies and seed dispersal. American Journal of Physical Anthropology 109:365-386.

LETOUZEY, R. 1968. Etudes phytogéographiques du Cameroun. Editions Paul Lechevalier, Paris. 511 pp.

LETOUZEY, R. 1970. Manuel de botanique forestière: Afrique tropicale. Centre technique forestier tropical, Nogent-sur-Marne.

LIEBERMAN, M. \& LIEBERMAN, D. 1986. An experimental study of seed ingestion and germination in a plant-animal assemblage in Ghana. Journal of Tropical Ecology 2:113-126.

LUCAS, P. W. \& GORLETT, R. T. 1998. Seed dispersal by long-tailed macaques. American Journal of Primatology 45:29-44.

MAISELS, F. 1993. Gut passage rate in guenons and mangabeys: another indicator of a flexible feeding niche? Folia Primatologica 61:35-37.

MELNICK, D. J. \& PEARL, M. C. 1987. Cercopithecines in multimale groups: genetic diversity and population structure. Pp. 121-134 in Smuts, B. B., Cheney, D. L., Seyfarth, R. M., Wrangham, W. R. \& Struhsaker, T. T. (eds). Primate societies. University of Chicago Press, Chicago.

MUCHAAL, P. K. \& NGANDJUI, G. 1999. Impact of village hunting on wildlife populations in the western Dja Reserve, Cameroon. Conservation Biology 13:385-396.

OATES, J. F. 1999. Myth and reality in the rain forest. University of California Press, Berkeley. 310 pp.

POULSEN, J. R., CLARK, C. J., CONNOR, E. F \& SMITH, T. B. In press. Differential resource use by primates and hornbills: implications for seed dispersal. Ecology.

POULSEN, J. R., CLARK, C. J. \& SMITH, T. B. 2001. Seasonal variation in the feeding ecology of the grey-cheeked mangabey (Lophocebus albigena). American Journal of Primatology 54:91-105.

ROWELL, T. E. \& MITCHELL, B. J. 1991. Comparison of seed dispersal by guenons in Kenya and capuchins in Panama. Journal of Tropical Ecology 7:269-274.

SCHUPP, E. W. 1993. Quantity, quality and the effectiveness of seed dispersal by animals. Vegetatio 107/ 108:15-30.

SCHUPP, E. W., MILLERON, T. \& RUSSO, S. In press. Dispersal limitation and the origin and maintenance of species-rich tropical forests. In Levey, D. J., Silva, W. R. \& Galetti, M. (eds). Seed dispersal and frugivory: ecology, evolution, and conservation. CAB International, Wallingford.

SMITH, R. J. \& JUNGERS, W. L. 1997. Body mass in comparative primatology. Journal of Human Evolution 32:523-559.

STEVENSON, P. R. 2000. Seed dispersal by woolly monkeys (Lagothrix lagothricha) at Tinigua National Park, Colombia: dispersal distance, germination rate, and dispersal quality. American Journal of Primatology 50:275-289.

STRUHSAKER, T. T. 1999. Primate communities in Africa: the consequences of long-term evolution or the artifact of recent hunting? Pp. 289-294 in Fleagle, J. G., Janson, C. \& Reed, K. E. (eds). Primate communities. Cambridge University Press, Cambridge.

TAILFER, Y. 1989. La forêt dense d'Afrique centrale. Identification pratique des principaux arbres. ACCT, CTA. $96 \mathrm{pp}$.

TUTin, G. E. G., Williamson, E. A., ROGER, M. E. \& FERNANDEZ, M. 1991. A case study of a plant-animal relationship: Cola lizae and lowland gorillas in the Lopé Reserve, Gabon. Journal of Tropical Ecology 7:181-199.

TUTIN, C. E. G., HAM, R. M., WHITE, L. J. T. \& HARRISON, M. J. S. 1997. The primate community of the Lopé Reserve, Gabon: diets, responses to fruit scarcity, and effects on biomass. American Journal of Primatology 42:1-24.

VOYSEy, B. C., MaDOnAld, K. E., ROGERS, M. E., TUtin, C. E. G. \& PARnell, R. J. 1999a. Gorillas and seed dispersal in the Lopé Reserve, Gabon. I: Gorilla acquisition by trees. Journal of Tropical Ecology 15:23-38.

VOYSEY, B. C., MCDONALD, K. E., ROGERS, M. E., TUTIN, G. E. G. \& PARNELL, R. J. 1999b. Gorillas and seed dispersal in the Lopé Reserve, Gabon. II: Survival and growth of seedlings. Journal of Tropical Ecology 15:39-60. 
WHEELWRIGHT, N. T. \& ORIANS, G. H. 1982. Seed dispersal by animals: contrasts with pollen dispersal, problems of terminology and constraints on coevolution. American Naturalist 119:402-423.

WHITE, L. J. T., TUTIN, G. E. G. \& FERNANDEZ, M. 1991. Group composition and diet of forest elephants Loxodonta africana cyclotis Matschie 1900, in the Lopé Reserve, Gabon. African Journal of Ecology 31:181-199.

WHITESIDES, G. H., OATES, J. F., GREEN, S. M. \& KLUBERDANZ, R. P. 1988. Estimating primate densities from transects in a West African rain forest: a comparison of techniques. Journal of Animal Ecology 57:345-367.

WhitNEY, K. D., FOGIEL, M. F., LAMPERTi, A. M., HOLBROOK, K. M., STAUFFER, D. J., HARDESTY, B. D., PARKER, V. T. \& SMITH, T. B. 1998. Seed dispersal by Ceratogymna hornbills in the Dja Reserve, Cameroon. Journal of Tropical Ecology 14:351-371.

WHITNEY, K. D. \& SMITH, T. B. 1998. Habitat use and resource tracking by African Ceratogymna hornbills: implications for seed dispersal and forest conservation. Animal Conservation 1:107-117.

WILliAMSON, L. \& USONGO, L. 1996. Survey of gorillas Gorilla gorilla and chimpanzees Pan troglodytes in the Réserve de Faune du Dja, Cameroun. African Primates 2:67-72.

WRANGHAM, R. W., CHAPMAN, C. A. \& CHAPMAN, L. J. 1994. Seed dispersal by forest chimpanzees in Uganda. Journal of Tropical Ecology 10:355-368.

WRight, S. J., ZEBAllos, H., DOMinguEZ, I., GAllARDO, M. M., MORENO, M. C. \& IBANEZ, R. 1999. Poachers alter mammal abundance, seed dispersal, and seed predation in a Neotropical forest. Conservation Biology 14:227-239.

ZHANG, S.-Y. \& WANG, L.-X. 1995. Fruit consumption and seed dispersal of Ziziphus cinnamomum (Rhamnaceae) by two sympatric primates (Cebus apella and Ateles paniscus) in French Guiana. Biotropica 27:397-401. 
Appendix. List of seeds dispersed by primates in the Dja Reserve, Cameroon. GCM, grey-cheeked mangabey; WNG, white-nosed guenon; CRG, crowned guenon; MM, moustached monkey; CHP, chimpanzee, GOR, gorilla; UNK, unknown. Plant forms include: T, tree; L, lianas; H, herbs. The unknown column represents the assemblage of arboreal monkeys, and the data are derived from faeces deposited in seed traps and faeces found opportunistically on the forest floor. Nomenclature follows Hutchinson et al. (1963), Letouzey (1970) and Tailfer (1989).

\begin{tabular}{|c|c|c|c|c|c|c|c|c|}
\hline Seed species & Plant form & GCM & WNG & CRG & MM & CHP & GOR & UNK \\
\hline \multicolumn{9}{|l|}{ Anacardiaceae } \\
\hline Antrocaryon klaineanum & $\mathrm{T}$ & & & & & 1 & 1 & 1 \\
\hline Lannea welwitschii & $\mathrm{T}$ & 1 & 1 & & & & & 1 \\
\hline Pseudospondias microcarpa & $\mathrm{T}$ & & & & & & & 1 \\
\hline Sorindeia grandifolia & $\mathrm{T}$ & & & & & & & 1 \\
\hline Trichoscypha acuminata & $\mathrm{T}$ & & & & & 2 & 2 & \\
\hline Trichoscypha sp. & $\mathrm{T}$ & 2 & 2 & 2 & 2 & 2 & & \\
\hline \multicolumn{9}{|l|}{ Annonaceae } \\
\hline Annonidium mannii & $\mathrm{T}$ & 2 & & & & & & \\
\hline Artabotrys rufus & $\mathrm{L}$ & & & & & & & 1 \\
\hline Enantia chlorantha & $\mathrm{T}$ & 2 & & & & 1 & & \\
\hline Hexalobus crispiflorus & $\mathrm{T}$ & & 1 & & & & & \\
\hline Monanthotaxis sp. & $\mathrm{L}$ & & & & & & & 1 \\
\hline Pachypodanthium staudtii & $\mathrm{T}$ & & & & & & 1 & 1 \\
\hline Polyalthia suaveolens & $\mathrm{T}$ & 1,2 & 2 & 2 & 2 & & & \\
\hline Uvaria sp. 1 & $\mathrm{~L}$ & & & & & & & 1 \\
\hline Uvaria sp. 2 & $\mathrm{~L}$ & & & & & & & 1 \\
\hline Uvaria muricata & $\mathrm{L}$ & & & & & & & 1 \\
\hline Xylopia aethiopica & $\mathrm{T}$ & 2 & 2 & 2 & & & & \\
\hline Xylopia quintassii & $\mathrm{T}$ & 2 & & & & & & 1 \\
\hline Xylopia rubescens & $\mathrm{T}$ & 2 & 2 & 2 & & & & \\
\hline Xylopia parviflora & $\mathrm{T}$ & & & & & & & 1 \\
\hline Xylopia staudtii & $\mathrm{T}$ & 2 & 2 & 2 & & & & \\
\hline \multicolumn{9}{|l|}{ Apocynaceae } \\
\hline Landolphia sp. & $\mathrm{L}$ & 2 & & & & & 1 & \\
\hline Rauvolfia macrophylla & $\mathrm{T}$ & & & & & & & 1 \\
\hline Rauvolfia vomitoria & $\mathrm{T}$ & & & & & & & 1 \\
\hline \multicolumn{9}{|l|}{ Arecaceae } \\
\hline Eremospatha macrocarpa & $\mathrm{L}$ & 2 & & & & 1 & 1 & \\
\hline \multicolumn{9}{|l|}{ Bignoniaceae } \\
\hline Fernandoa adolfi-friderici & $\mathrm{H}$ & & & & & & 1 & \\
\hline \multicolumn{9}{|l|}{ Burseraceae } \\
\hline Dacyrodes edulis & $\mathrm{T}$ & & & & & & & 1 \\
\hline Canarium schweinfurthii & $\mathrm{T}$ & 2 & 2 & 2 & & & & \\
\hline Santiria trimera & $\mathrm{T}$ & & 1 & & & & & 1 \\
\hline \multicolumn{9}{|l|}{ Caesalpinioideae } \\
\hline Dialium guineensis & $\mathrm{T}$ & 1 & & & & & & 1 \\
\hline Dialium dinklagei & $\mathrm{T}$ & & & & & & & 1 \\
\hline Erythrophleum suaveolens & $\mathrm{T}$ & 1 & & & & 1 & & \\
\hline \multicolumn{9}{|l|}{ Celastraceae } \\
\hline Salacia sp. 1 & $\mathrm{~L}$ & & & & & & & 1 \\
\hline Salacia sp. 2 & $\mathrm{~L}$ & & & & & & & 1 \\
\hline \multicolumn{9}{|l|}{ Clusiaceae } \\
\hline Garcinia sp. 1 & $\mathrm{~T}$ & 2 & 2 & 2 & 2 & & & 1 \\
\hline Garcinia sp. 2 & $\mathrm{~T}$ & 1 & 1 & & & & & 1 \\
\hline Pentadesma sp. & $\mathrm{T}$ & & & & & & & 1 \\
\hline Symphonia globulifera & $\mathrm{T}$ & & & & & & & 1 \\
\hline \multicolumn{9}{|l|}{ Combretaceae } \\
\hline Terminalia superba & $\mathrm{T}$ & & 1 & & & & & \\
\hline \multicolumn{9}{|l|}{ Connaraceae } \\
\hline Agelaea sp. & $\mathrm{L}$ & & & & & & & 1 \\
\hline Cnestis sp. & $\mathrm{L}$ & & & & & & & 1 \\
\hline Roureopsis obliquifoliolata & $\mathrm{L}$ & & & & & & & 1 \\
\hline
\end{tabular}


Appendix. Continued

\begin{tabular}{|c|c|c|c|c|c|c|c|c|}
\hline Seed species & Plant form & GCM & WNG & CRG & MM & CHP & GOR & UNK \\
\hline \multicolumn{9}{|l|}{ Dichapetalaceae } \\
\hline Dichapetalum heudlotii & $\mathrm{L}$ & 1 & & & & & & 1 \\
\hline Dichapetalum mombuttense & $\mathrm{L}$ & 1 & & & & & & 1 \\
\hline Tapura africana & $\mathrm{L}$ & & & & & & & 1 \\
\hline \multicolumn{9}{|l|}{ Dilleniaceae } \\
\hline Tetracera podotricha & $\mathrm{L}$ & & & & & & & 1 \\
\hline Tetracera potatoria & $\mathrm{L}$ & & & & & & & 1 \\
\hline \multicolumn{9}{|l|}{ Ebenaceae } \\
\hline Diospyros conocarpa & $\mathrm{T}$ & & & & & & & 1 \\
\hline \multicolumn{9}{|l|}{ Euphorbiaceae } \\
\hline Antidesma sp. & $\mathrm{T}$ & & & & & & & 1 \\
\hline Discoglypremna caloneura & $\mathrm{T}$ & 1 & & & & & & 1 \\
\hline Drypetes capillipes & $\mathrm{T}$ & & & & & & & 1 \\
\hline Drvpetes chevalieri & $\mathrm{T}$ & 1 & 1 & & & & & 1 \\
\hline Drypetes gossweileri & $\mathrm{T}$ & & & & & & & 1 \\
\hline Euphorbiaceae sp. & $\mathrm{T}$ & 1 & 1 & & 1 & & & 1 \\
\hline Macaranga sp. 1 & $\mathrm{~T}$ & 1 & 1 & & & & & 1 \\
\hline Macaranga sp. 2 & $\mathrm{~T}$ & 1 & 1 & & & & & 1 \\
\hline Margaritaria discoidea & $\mathrm{T}$ & 1 & & & & & & 1 \\
\hline Plagiostylus africanus & $\mathrm{T}$ & 1 & 1 & & & & 1 & 1 \\
\hline Uapaca paludosa & $\mathrm{T}$ & 1,2 & 1 & 1 & 1 & 1 & 1 & 1 \\
\hline Uapaca acuminata & $\mathrm{T}$ & 1,2 & 1 & 1 & 1 & 1 & 1 & 1 \\
\hline Uapaca guineensis & $\mathrm{T}$ & 1,2 & 1 & 1 & 1 & 1 & 1 & 1 \\
\hline Uapaca vanhouttei & $\mathrm{T}$ & 1,2 & 1 & 1 & 1 & 1 & 1 & 1 \\
\hline \multicolumn{9}{|l|}{ Flacourtiaceae } \\
\hline Caloncoba glauca & $\mathrm{T}$ & & & & & & & 1 \\
\hline Casearia barteri & $\mathrm{T}$ & & & & & & & 1 \\
\hline Lindackeria dentata & $\mathrm{T}$ & & & & & & & 1 \\
\hline Scottelia mimfiensis & $\mathrm{T}$ & & & & & & & 1 \\
\hline \multicolumn{9}{|l|}{ Irvingiaceae } \\
\hline Irvingia grandifolia & $\mathrm{T}$ & & & & & & & \\
\hline Klainedoxa gabonensis & $\mathrm{T}$ & 2 & 2 & 2 & & & & \\
\hline \multirow{2}{*}{\multicolumn{9}{|c|}{$\begin{array}{l}\text { Klameaoxa micropnylla } \\
\text { Lauraceae }\end{array}$}} \\
\hline & & & & & & & & \\
\hline Beilschmiedia sp. & $\mathrm{T}$ & & & & & & & 1 \\
\hline \multicolumn{9}{|l|}{ Linaceae } \\
\hline Hugonia platysepala & $\mathrm{L}$ & & & & & & & 1 \\
\hline \multicolumn{9}{|l|}{ Loganiaceae } \\
\hline Strychnos sp. & $\mathrm{L}$ & & & & & & & 1 \\
\hline \multicolumn{9}{|l|}{ Marantaceae } \\
\hline Megaphrynium macrostachyum & $\mathrm{H}$ & & & & & & & 1 \\
\hline Sarcophrynium brachystachys & $\mathrm{H}$ & & & & & 1 & 1 & 1 \\
\hline Sarcophrynium prionogonium & $\mathrm{H}$ & & & & & 1 & & \\
\hline \multicolumn{9}{|l|}{ Meliaceae } \\
\hline Guarea thompsonii & $\mathrm{T}$ & & 2 & & & & & \\
\hline Trichilia welwitschii & $\mathrm{T}$ & 2 & & & & & & 1 \\
\hline Turreanthus africanus & $\mathrm{T}$ & 1 & & & & & & 1 \\
\hline \multicolumn{9}{|l|}{$\begin{array}{l}\text { Moraceae } \\
\text { M }\end{array}$} \\
\hline Ficus spp. & $\mathrm{L}, \mathrm{T}$ & 1 & 1 & 1 & 1 & 1 & 1 & 1 \\
\hline Musanga cecropioides & $\mathrm{T}$ & & & & & & & 1 \\
\hline Myrianthus arboreus & $\mathrm{T}$ & 1 & & & & 1 & 1 & 1 \\
\hline Trilepisium madagascariense & $\mathrm{T}$ & 2 & & & & & & \\
\hline \multicolumn{9}{|l|}{ Myristicaceae } \\
\hline Coelocaryon preussii & $\mathrm{T}$ & 1 & & & & & & \\
\hline Pycnanthus angolensis & $\mathrm{T}$ & 2 & & & & & & \\
\hline Staudtia kamerunensis & $\mathrm{T}$ & 2 & 2 & 2 & 2 & & & \\
\hline
\end{tabular}


Appendix. Continued

\begin{tabular}{|c|c|c|c|c|c|c|c|c|}
\hline Seed species & Plant form & GCM & WNG & GRG & MM & СHP & GOR & UNK \\
\hline \multicolumn{9}{|l|}{ Olacaceae } \\
\hline Heisteria zimmereri & $\mathrm{T}$ & 1,2 & 1 & 2 & 2 & & & 1 \\
\hline Ongokea gore & $\mathrm{T}$ & 2 & & & & & & \\
\hline Strombosia grandifolia & $\mathrm{T}$ & 2 & 2 & & & & & 1 \\
\hline Strombosia pustulata & $\mathrm{T}$ & 2 & 2 & 2 & 2 & & & \\
\hline Strombosia scheffleri & $\mathrm{T}$ & 2 & 2 & 2 & & & & 1 \\
\hline Strombosiopsis tetranda & $\mathrm{T}$ & 2 & 2 & 2 & & & & \\
\hline \multicolumn{9}{|l|}{ Pandaceae } \\
\hline Microdesmis puberula & $\mathrm{T}$ & & & & & & & 1 \\
\hline \multicolumn{9}{|l|}{ Rhamnaceae } \\
\hline Maesopsis eminii & $\mathrm{T}$ & 1 & & & & & & \\
\hline \multicolumn{9}{|l|}{ Rubiaceae } \\
\hline Aidia micrantha & $\mathrm{T}$ & & & & & & & 1 \\
\hline Bertiera sp. & $\mathrm{T}$ & & & & & & & 1 \\
\hline Cephaelis densinervia & $\mathrm{T}$ & & & & & & & 1 \\
\hline Cephaelis mannii & $\mathrm{T}$ & 1 & 1 & & & & & 1 \\
\hline Psychotria cf. vogeliana & $\mathrm{T}$ & & & & & & & 1 \\
\hline Trichostachys sp. & $\mathrm{T}$ & 1 & 1 & & & 1 & & \\
\hline \multicolumn{9}{|l|}{ Rutaceae } \\
\hline Fagara macrophylla & $\mathrm{T}$ & & & & & & & 1 \\
\hline Fagara poggei & $\mathrm{L}$ & & & & & & & 1 \\
\hline Fagara viridis & $\mathrm{L}$ & & & & & & & 1 \\
\hline Zanthoxylum heitzii & $\mathrm{T}$ & 1 & & & & & & \\
\hline \multicolumn{9}{|l|}{ Sapindaceae } \\
\hline Chytranthus angustifolius & $\mathrm{T}$ & & & & & & & 1 \\
\hline Chytranthus sp. & $\mathrm{T}$ & & & & & & & 1 \\
\hline \multicolumn{9}{|l|}{ Sapotaceae } \\
\hline Afrosersalisia sp. & $\mathrm{T}$ & & & & & & & 1 \\
\hline Aningeria robusta & $\mathrm{T}$ & & & & & & & 1 \\
\hline Donella ubanguienesis & $\mathrm{T}$ & & & & & & & 1 \\
\hline Gambeya boukokoensis & $\mathrm{T}$ & 1 & & & 1 & & 1 & \\
\hline Gambeya lacourtiana & $\mathrm{T}$ & & 1 & & & & & \\
\hline Gambeya perpulchra & $\mathrm{T}$ & & & & & & & 1 \\
\hline Manilkara sp. & $\mathrm{T}$ & & & & & & & 1 \\
\hline Sapotaceae sp. & $\mathrm{T}$ & & & & & & & 1 \\
\hline Synsepalum longicuneatum & $\mathrm{T}$ & & & & & & & 1 \\
\hline Synsepalum stipulatum & $\mathrm{T}$ & 1 & 1 & & & & & 1 \\
\hline Tridesmostemon omphalocarpoides & $\mathrm{T}$ & & & & & 1 & & \\
\hline \multicolumn{9}{|l|}{ Sterculiaceae } \\
\hline Sterculia tragacantha & $\mathrm{T}$ & 1 & & & & & & \\
\hline \multicolumn{9}{|l|}{ Tiliaceae } \\
\hline Duboscia macrocarpa & $\mathrm{T}$ & & & & & 1 & 1 & 1 \\
\hline Grewia coriacea & $\mathrm{T}$ & & & & & & & 1 \\
\hline Grewia hookeriana & $\mathrm{L}$ & 1 & 1 & & & 1 & 1 & 1 \\
\hline \multicolumn{9}{|l|}{ Ulmaceae } \\
\hline Celtis adolfi-fredrici & $\mathrm{T}$ & & & & & & & 1 \\
\hline Celtis mildbraedii & $\mathrm{T}$ & & & & & & & 1 \\
\hline \multicolumn{9}{|l|}{ Verbenaceae } \\
\hline Vitex grandifolia & $\mathrm{T}$ & 2 & & 2 & 2 & 1 & 1 & 1 \\
\hline Vitex ferruginea & $\mathrm{T}$ & & & & & & & 1 \\
\hline Vitex thyrsiflora & $\mathrm{L}$ & & & & & & & 1 \\
\hline \multicolumn{9}{|l|}{ Vitaeceae } \\
\hline Cissus dinklagei & $\mathrm{L}$ & 1 & 1 & 1 & & & & 1 \\
\hline Cissus diffusiflora & $\mathrm{L}$ & & & & & & & 1 \\
\hline Cissus producta & $\mathrm{L}$ & & 1 & & & & & 1 \\
\hline \multicolumn{9}{|l|}{ Zingiberaceae } \\
\hline Afromomum dalzielii & $\mathrm{H}$ & 1 & & 1 & 1 & 1 & 1 & 1 \\
\hline
\end{tabular}


Appendix. Continued

\begin{tabular}{|c|c|c|c|c|c|c|c|c|}
\hline Seed species & Plant form & GCM & WNG & CRG & $\mathrm{MM}$ & $\mathrm{CHP}$ & GOR & UNK \\
\hline Unidentified & & $29^{1}, 1^{2}$ & $12^{1}$ & $2^{1}, 1^{2}$ & $2^{1}$ & $24^{1}$ & $7^{1}$ & $2^{1}$ \\
\hline No. species passed & & 33 & 23 & 6 & 6 & 19 & 18 & 97 \\
\hline Trees & & 27 & 19 & 4 & 5 & 13 & 10 & 68 \\
\hline Lianas & & 5 & 4 & 2 & 1 & 3 & 5 & 24 \\
\hline Herbs & & 1 & 0 & 1 & 1 & 3 & 3 & 3 \\
\hline No. species drop-dispersed & & 29 & 15 & 14 & 8 & 6 & 3 & - \\
\hline Trees & & 27 & 15 & 14 & 8 & 2 & 1 & - \\
\hline Lianas & & 2 & 0 & 0 & 0 & 0 & 0 & - \\
\hline Herbs & & 0 & 0 & 0 & 0 & 0 & 0 & - \\
\hline
\end{tabular}

${ }^{1}$ Seeds passed without physical damage.

${ }^{2}$ Seeds dropped from cheek pouches or hands. 